\title{
SIMPLICITY IN LEGISLATIVE \\ DRAFTING AND REWRITING TAX \\ LEGISLATION
}

\author{
Sir Ivor Richardson*
}

The search for simplicity in legislative drafting affects all legislatures. It is also central to the work of the New Zealand Law Commission and of governments in other comparable jurisdictions. Rather than exploring a range of statutes in various jurisdictions, this article focuses on income tax. It does so for two reasons. The first is that income tax has been crucial to the funding of government in common law jurisdictions and to achieving a legislative balance between simplicity and other criteria of an acceptable tax system. The second is that we can draw on three recent projects to rewrite income tax legislation - in Australia, the United Kingdom and New Zealand.

\section{INTRODUCTION}

Section 5(1)(d) of the Law Commission Act 1985 directs the Commission "to advise the Minister of Justice ... on ways in which the law of New Zealand can be made as understandable and accessible as is practicable". In doing so, the Commission is to "have regard to the desirability of simplifying the expression and content of the law, as far as that is practicable."1

Those directions were also reflected in the broad reference on Legislation and its Interpretation ${ }^{2}$ from the Minister which led to a series of Law Commission reports. The two of widest application are A New Interpretation Act to avoid "Prolixity and Tautology"3 (which led to the implementation of the Interpretation Act 1999) and The Format of Legislation. ${ }^{4}$

* Distinguished Fellow, Faculty of Law, Victoria University of Wellington.

1 Law Commission Act 1985, s 5(2)(b).

2 Law Commission Legislation and its Interpretation (NZLC TOR, 1986).

3 Law Commission A New Interpretation Act to avoid "Prolixity and Tautology" (NZLC R17, 1990).

4 Law Commission The Format of Legislation (NZLC R27, 1993). 
The latter report emphasised that those who are expected to know, obey, apply and advise on the law must be helped, so far as is practicable to understand it; ${ }^{5}$ supported clearer and more straightforward legislative drafting with shorter sentences, use of the active voice and use of everyday language; ${ }^{6}$ proposed various changes in the formatting of enactments; ${ }^{7}$ and commended aids to understanding such as indexes, explanatory notes, examples, flow charts and the use of formulas, maps and diagrams ${ }^{8}$ - all since used to a greater or lesser extent in our statute book.

As well, the Law Commission's initiatives have included the production of Cabinet Office Manuals requiring ministers to certify compliance with the Legislation Advisory Committee's guidelines on the preparation of legislation and the preparation of the Legislative Manual which sets out standards to be followed in the drafting of legislation. ${ }^{9}$

Similar initiatives have been taken in various other comparable jurisdictions and there is an immense volume of published material by legislative drafters and academic and other professional commentators.

As the then Attorney-General for England and Wales the Rt Hon Sir Patrick Mayhew said, the ultimate object must be: ${ }^{10}$

... to give reliable expression to the will of Parliament, and in a manner that may, as readily as is practicable, enable the public, for whom Parliament legislates, to perceive the parliamentary will with

clarity, and to order its future behaviour accordingly.

Many subjects are complex - some particularly so. Rather than dipping into a range of statutes and analysing their particular problems, this article focuses on income tax. It does so for two reasons. The first is that income tax has been crucial to the funding of government for over 60 years and, while simplicity may be an objective of the legislation, it can never be the sole criterion. Fairness, certainty, efficient collectability and acceptability of wider economic outcomes are some of the other objectives which become more and more important as the burden of taxes increases. The second is that we can draw on and compare the recent efforts to rewrite income tax in the three jurisdictions: Australia, the United Kingdom and New Zealand.

5 At [6].

6 At [7]

7 At [19]-[42].

8 At [42]-[43].

9 Law Commission The Format of Legislation, above n 4, at Appendix E.

10 Patrick Mayhew "Can Legislation Ever be Simple, Clear and Certain?" (1990) 11 Stat LR 1 at 1. 
Before doing so I pause to note, first, an early 20th century illustration of the quest for an unobtainable simplicity and, second, the pattern of increases over time in the length of the income tax legislation in the three jurisdictions and the resources committed to collecting the legislation.

\section{A The United Kingdom Tax Codification Committee of 1927}

In pursuit of the goal of simplicity a committee was appointed by the then Chancellor of the Exchequer, the Rt Hon Winston Churchill: ${ }^{11}$

... to prepare a draft of a Bill or Bills, to codify the law relating to Income Tax, with the special aim of making the law as intelligible to the taxpayer as the nature of the legislation admits.

Nine years later the Committee, by then presided over by Lord Macmillan and which included some of the leading tax experts of the day, presented its report in the course of which it said: ${ }^{12}$

... to expect from us a codification of the law of income tax which the layman could easily read and understand was a vain hope, which only the uninstructed could cherish, ... Income tax must, by its very

nature, be abstract and technical, and can never be easy reading.

The note "Income Tax Report" in The Law Journal recorded that the two volume report included a draft Bill containing 417 clauses, eight schedules plus appendices, which preserved the existing law substantially unaltered. ${ }^{13}$

Suffering the fate of many lengthy inquiries, the Committee's draft Bill was not enacted and the Income Tax Act 1918 (UK) (with amendments) continued in force until repealed and replaced by the consolidating Income Tax Act 1952 (UK).

\section{$B$ Increases in the Length of the Income Tax Legislation and the Resources Committed to its Collection}

\section{Australia}

Substantial governmental reviews of tax administration in Australia and New Zealand were published within a few months of each other in 1993-1994 ${ }^{14}$ and the data in this section of the paper is largely drawn from the article, "Directions for Tax Administration: Two Recent Reports". ${ }^{15}$

11 Income Tax Codification Committee Report and Appendices (HM Stationery Office, Cmnd 5131, 1936) vol 1 at 5 .

12 Ibid, at $18-19$

13 "Income Tax Report" (1936) LXXXI The Law Journal 269 at 270; see also, "Income Tax Codification" (1936) 181 The Law Times 289 at 289.

14 Joint Committee of Public Accounts An Assessment of Tax: A Report on an Inquiry into the Australian Taxation Office (AGPS, Report No 326, November 1993); Organisational Review Committee Organisational Review of the Inland Revenue Department: Report to the Minister of Revenue (and on tax policy, also to the Minister of Finance) (New Zealand Government, April 1994). 
The legislative provisions then governing the administration of the tax system dated back to the introduction of the Income Tax Assessment Act 1936 in Australia and the Land and Income Tax Act 1916 in New Zealand. ${ }^{16}$

The Australian Tax Office (ATO) then employed over 18,000 people operating out of 25 branch offices and 17 regional offices. It expended over $\$ 1.12$ billion and collected over $\$ 74.7$ billion in 1992-1993 from over 10 million taxpayers. In 1911-1912, the total staff at the ATO was only 105 and as late as 1939-1940 income tax collected totalled only £16.4 million. ${ }^{17}$ The legislation had grown from 126 pages in 1936 to over 5,000 in $1993 .^{18}$

The Australian report concluded that the Income Tax Assessment Act was in desperate need of a comprehensive overhaul and recommended what it described as a priority simplification redraft within two years and the full simplification of the Act within five years.

\section{New Zealand}

In 1994, the New Zealand Inland Revenue Department employed some 5,800 people in 35 offices. Its annual budget was $\$ 380$ million and it collected some $\$ 21$ billion net revenue. In 1914, income tax yielded only $£ 554,000$ and $£ 14.8$ million in 1939. In subsequent years, wartime needs and then the development of the welfare state required substantial funding from a mass taxation. ${ }^{19}$ The legislation had grown from 169 sections and 43 pages (for both land tax and income tax) in 1916, to 246 sections and 179 pages in 1954, to 436 sections and 543 pages (for income tax alone) in 1976 with a dramatic surge to 833 sections and 2,038 pages in $1993 .{ }^{20}$

The Organisational Review Committee report supported the changed approach to legislative drafting recommended in 1993 by the Working Party on the Reorganisation of the Income Tax Act $1976,{ }^{21}$ following on from the recommendations of the Waugh Committee in 1990. The Minister of Revenue, the Hon Wyatt Creech, had moved that the Working Party's report, which included its three volume draft Bill, be referred directly to the Finance and Expenditure Committee:22

15 Ivor Richardson "Directions for Tax Administration: Two Recent Reports" (1994) 22 FL Rev 461.

16 Ibid, at 462.

17 Ibid.

18 Ibid, at 467.

19 Ibid, at 462.

20 Ibid, at 467.

21 Working Party on the Reorganisation of the Income Tax Act Second Report of the Working Party (Preliminary Paper B31, September 1993).

22 (23 September 1993) 538 NZPD 18362. 
... the Income Tax Act 1976 is the largest, most complex and most frequently amended legislation on the statute book. The 1976 Act is poorly structured and extremely difficult to follow, even for people who are expert in tax legislation. It imposes needlessly high costs on the business sector, and the Government seeks as a matter of policy to keep compliance costs down.

\section{United Kingdom}

The genesis of the United Kingdom rewrite was the Budget Statement of the then Chancellor of the Exchequer, the Rt Hon Kenneth Clarke, on 28 November 1995. He said: ${ }^{23}$

Tax law has become too long and complicated. ... Some experts have described it as incomprehensible. The Inland Revenue will shortly be publishing a report on tax simplification. We will propose that the Revenue tax code is rewritten in plain English - a major task.

Sabine in A Short History of Taxation writes: ${ }^{24}$

By the end of the war [1918] income tax had changed out of all recognition. No longer was it the simple Victorian mechanism with a uniform rate of pence in the pound. It was now a much more complex apparatus admitting both differentiation in the form of an earned income relief, and graduation in the shape of a supertax, with the income tax rate at $6 \mathrm{~s}$. and the maximum supertax at $4 \mathrm{~s}$. $6 \mathrm{~d}$. ... The most remarkable change, however, was in yield from some $£ 34$ millions pre-war to nearly £585 millions in 1918.

He notes that World War II also saw a sharp rise in the tax take, from $£ 371$ million in 1938 to $£ 1,426$ million in 1945 while the new excess profits tax brought in close to £500 million at its maximum. ${ }^{25}$ Sabine goes on to remark that well within living memory (presumably sometime before World War I) it yielded only $£ 15$ million compared with $£ 45$ million from customs and excise. ${ }^{26}$

The legislation grew from 180 pages in 1918 to 530 in the 1952 consolidation with rapid increases in direct taxes legislation over the next 40 years. When the still incomplete rewrite ended in 2010, the seven rewritten Acts ${ }^{27}$ ran to over 6,000 pages and excluded capital gains and other remaining legislation.

\section{An aside}

The simplification challenges which the three Governments faced could have been worse.

23 (28 November 1995) 267 GBPD HC 1066

24 BEV Sabine A Short History of Taxation (Butterworths, London, 1980) at 139.

25 At 142

26 At 130 .

27 Listed at Part III below. 
An article in a recent edition of The Economist titled "Guides through the swamp" begins in this way: ${ }^{28}$

Paying tax always hurts. But America's tax code seems designed to make it hurt as much as possible. It contains 3.8m words, and was changed 579 times in 2010 alone. Taxpayers must wade through a swamp of gobbledygook: tax compliance consumes 6.1 billion man-hours annually, according to the Internal Revenue Service (IRS). That's the equivalent of 3m people working full time, year-round - more than the entire federal workforce. Each year, Joe Taxpayer must sign a thick return that he cannot plausibly understand. And woe betide him if any of its contents should turn out to be inaccurate.

The obvious solution would be to simplify the tax code. The IRS's National Taxpayer Advocate begs Congress every year to do exactly this. But it never will, so most taxpayers hire a guide.

Tax advisers and preparers benefit handsomely from politicians' addiction to loopholes and unclear English. Of the $140 \mathrm{~m}$ individuals and families who file tax returns each year in America, $60 \%$ pay someone else to fill out forms for them. Another $29 \%$ buy tax-preparation software, either to install on their computers, or more often these days, online.

\section{THE REWRITE OF AUSTRALIAN TAX LEGISLATION}

Regrettably, the rewrite of the Australian legislation proposed by the Commonwealth Parliament's Joint Committee of Public Accounts in 1993 was only partly completed before it was shelved by the Liberal-National Coalition Government in mid-1998. ${ }^{29}$

In an early article following the Labor Government's commitment to the rewrite, titled at the time the "Taxation Laws Improvement Project" (TLIP), Brian Nolan and Tom Reid discussed the project at some length. ${ }^{30}$ They suggested various steps required to achieve a satisfactory outcome including a detailed review leading to identifying the target categories of readers of the legislation and their respective literacy skills. They also proposed testing the readability of the proposed legislation accordingly. ${ }^{31}$

Writing in 2003, Richard Krever noted the enacting of the first step, the Income Tax Assessment Act 1997 and the Taxation Laws Amendment Acts 1998 which followed, ${ }^{32}$ and went on to explain: ${ }^{33}$

28 "Guides through the swamp: A big shake-up for America's tax-preparation industry" The Economist (online ed, New York, 24 March 2012) at 66.

29 Richard Krever "Taming Complexity in Australian Income Tax" (2003) 25 Syd LR 467 at 497.

30 Brian Nolan and Tom Reid "Re-Writing the Tax Act" (1994) 22 FL Rev 448.

31 At 457-460.

32 Krever, above n 29, at 493.

33 At 497. 
The government never explicitly conceded the validity of the growing chorus of criticism for its redraft project, but by the time the second tranche of plain English legislation had been released it was obvious to everyone that clearer language was not bringing clearer tax law. In mid-1998, when only one-third of the law had been replaced with plain English text, the government quietly shelved the simplification project in the context of appointing a Review of Business Taxation.

David Wallis added that: ${ }^{34}$

The scope of the project was unfortunately narrow, restricted to only the rewording, renumbering, and restructuring of the existing Act - a redrafting into "plain English". ... "to replace the layers of obscurity and uncertainty with simple, clear and unambiguous provisions".

As many had expected, TLIP did not fulfil its promised objectives.

He went on to discuss sources and problems of complexity, escalating costs of compliance and the confusing language of the legislation and limits to simplification. He noted with concern that tax legislation was then largely contained in the two statutes, the original Income Tax Assessment Act 1936 (Cth) (ITAA36) and the Income Tax Assessment Act 1997 (Cth) (ITAA97) and their amendments, in different drafting styles and with the legislation by then exceeding 8,000 pages. $^{35}$

That was not the end of the rewrite saga. Dr Stephen Barkoczy explains how the "New Tax System" reforms stemming from the Review of Business Taxation were placed in the ITAA97, not the ITAA36. Spent provisions in the ITAA36 were repealed and a number of miscellaneous provisions in the ITAA36 were rewritten and transferred into the ITAA97 - adopting the new structure, plain language, greater standardisation, new numbering system and revised layout, all hallmarks of the rewrite program. ${ }^{36}$ These steps resulted in a burgeoning ITAA97 and a shrinking ITAA36.

For its part the succeeding Australian Labor Government has indicated that, as part of its ongoing reforms, it will gradually transfer the remaining sections of the ITAA36 into the ITAA97. The Taxation Laws Amendment (Transfer of Provisions) Act 2010 (Cth) transferred a number of ITAA36 provisions into the ITAA97.

Dr Barkoczy comments wryly "[a]lthough the ITAA36 is steadily shrinking, the day that Australia will once again have a single Assessment Act is still some time away."37

34 David Wallis "The Tax Complexity Crisis" (2006) 35 AT Rev 274 at 275 (citations omitted).

35 At 276 .

36 Stephen Barkoczy Foundations of Taxation Law (4th ed, CCH Australia, Sydney, 2012) at 95-101.

37 Ibid, at 99. 


\section{THE REWRITE IN THE UNITED KINGDOM}

The rewrite, signalled by the Chancellor of the Exchequer in $1995,{ }^{38}$ was initially anticipated by the Department of Revenue to be completed in around five years. It ended in 2010 after the passage of seven rewritten tax Acts. These were the: Capital Allowances Act 2001; Income Tax (Earnings and Pensions) Act 2003; Income Tax (Trading and Other Income) Act 2005; Income Tax Act 2007; Corporation Tax Act 2009; Corporation Tax Act 2010; and the Taxation (International and Other Provisions) Act 2010 (all UK).

Reflecting the economic and social significance of taxes for the funding of governments, there has been a flood of published material over the last 30 years on simplifying tax legislation and drafting in plain English. Malcolm James' "Tax Simplification: The Impossible Dream"39 and Ruth Sullivan's "Some Implications of Plain Language Drafting" 40 are two long and illuminating discussions with copious references to the literature. But it is sufficient for present purposes to refer briefly to the reasons why the Government abandoned the project part way through and to assess the resulting outcome.

David Salter provides an early assessment of the rewrite. ${ }^{41}$ He notes that waning support led to curtailment of its breadth early in 2010 to exclude capital gains tax, inheritance and other complete tax codes ${ }^{42}$ and concludes that curtailing the project "means that the fiscal landscape in the case of direct taxes resembles a patchwork quilt of rewritten and old-style legislation."43 He had earlier noted that the resource intensive nature of the rewrite was a significant factor in the Labour Government's decision to bring the rewrite to an end. ${ }^{44} \mathrm{He}$ also mentioned that the direct costs of the project team were about $£ 3$ million per year. Additional to this were incidental costs to Her Majesty's Revenue and Customs and private sector costs of participation in the elaborate preparliamentary and parliamentary procedures and, on top of all that, there were the implementation costs. $^{45}$

38 See above n 23 ((28 November 1995) 267 GBPD HC 1066).

39 Malcolm James "Tax Simplification: the Impossible Dream" [2008] BTR 392.

40 Ruth Sullivan "Some Implications of Plain Language Drafting" (2001) 22 Stat LR 175.

41 David Salter "The Tax Law Rewrite in the United Kingdom: Plus ça change plus c`est la même chose?" [2010] BTR 671.

42 At 681.

43 At 682 .

44 At 674 .

45 At 685 
Early in 2008 the then Shadow Chancellor of the Exchequer, George Osborne, established a Working Party which in its final report recommended: ${ }^{46}$

(1) the establishment of an Office of Tax Simplification to examine the existing tax code and make proposals for change;

(2) the establishment of a new Joint Parliamentary Select Committee to strengthen parliamentary oversight of tax law, thereby improving the scrutiny of government proposals. It would also examine and make recommendations on proposals presented to it by the Office of Tax Simplification; and

(3) that any changes to tax law with technical content should be proposed no later than the Pre-Budget Report before the introduction of the Finance Bill to give time for adequate consultation and prevent hasty and ill-considered legislation.

The final report adds that the proposed committee had not been established.

The subsequent note by David Salter commented that in its post-implementation qualitative review, the Committee expressed concern that the opportunity was missed to tackle the perceived inherent complexity of the United Kingdom tax legislation. ${ }^{47} \mathrm{Mr}$ Salter also noted the Coalition Government's "setting up of the Office of Tax Simplification and its commitment to restore the UK tax system's reputation for 'predictability, stability and simplicity'." 48

\section{NEW ZEALAND}

The report of the Organisational Review Committee ${ }^{49}$ identified fundamental changes in the drafting of legislation as a key issue, and invited the Chief Executive of the Inland Revenue Department to report to the Cabinet Strategy Committee by 1 June 1994 on a process for progressing legislative changes. ${ }^{50}$

By the time the Organisational Review Committee reported in April 1994 the Government had already implemented the new Generic Tax Policy Process (GTPP) recommended by the Committee in December 1993. The GTPP provided a clear strategic focus for tax policy development through a structured process involving more formalised consultation in a three year rolling work programme

46 Taxation Working Party Making Taxes Simpler: The final report of a working party chaired by Lord Howe of Aberavon (Conservative Party, July 2008) cited in Lynne Oats and David Salter "Section 91 and Schedule 26: redundant reliefs - repeal" [2011] BTR 469 at 469.

47 David Salter "The Ipsos MORI review of rewritten income tax legislation - contrasting and converging viewpoints" [2011] BTR 622 at 625.

48 Ibid.

49 Organisational Review Committee, above n 14.

50 At 22. 
over five phases: Strategic, Tactical, Operational, Legislative, and Implementation and Review. The Government had also committed itself to the rewriting of the income tax legislation over a five year period and draft legislation reordering the legislation was before the House of Representatives. It was enacted that year as the Income Tax Act 1994.

The April 1994 report went on to endorse the high priority accorded to the rewrite and recommended its inclusion in the planning phases of the GTPP and completion as soon as possible. ${ }^{51}$ Appendix G provided a blueprint for the Legislation and Implementation and Review phases, ${ }^{52}$ and Appendix H, "Tax Legislation", explained the deficiencies in the design of the legislation and the drafting style requirements. ${ }^{53}$

The following year the Minister of Finance established the Rewrite Advisory Panel (RAP or Panel) to consider and advise on issues arising during the rewriting of the 1994 Act. The RAP consists of a chair and representatives from the Inland Revenue Department, Treasury, the New Zealand Institute of Chartered Accountants and the New Zealand Law Society. Colin Blair, a very experienced chartered accountant, chaired the Panel from 1995 to 2003, I did so from late-2003 to 2008 and David McLay, a very experienced tax lawyer, has done so since 2008.

The Finance and Expenditure Select Committee had been reviewing the Bill for 10 months before reporting it back to the House of Representatives on 19 December 2003. The Income Tax Act 2004, assented to on 7 May 2004, incorporated the rewriting up to Part E and also included the nonredrafted balance of the legislation, Parts F to O. It ran to 2,089 pages. The Income Tax Act 2007 rewrote the remaining Parts, now F to $\mathrm{Z}$, as well as the schedules, and made consequential amendments and some reordering changes to Parts A to E.

The clear intent was that the rewrite should not change the law. In 2004, the RAP took on the additional role of considering potential unintended change issues under the Income Tax Act 2004 and those emerging in the redrafting process for the rest of the legislation. The website it developed recorded progress on the rewrite and the RAP posted full minutes of its meetings on the website. The website and minutes also recorded progress on all potential unintended consequences as they were raised by any users of the legislation.

If the RAP considered there had been an unintended change in the law it recommended to the Minister whether the redraft should be amended or the change should be retained. Any necessary correcting legislation followed promptly. Only 51 potential unintended consequences had been raised when, as chair of the Panel, I briefed members of the Finance and Expenditure Committee about the 2006 Bill.

\footnotetext{
51 Organisational Review Committee, above n 14, at 85.

52 Ibid, at 71-72.

53 Ibid, at $77-79$.
} 
Extensive consultation checks were also built into the drafting process. As drafts of segments were completed, they were referred to the RAP for comment. In the lead-up to public consultation the drafting team also subjected the drafts to reports from specialists both within and outside the Department of Revenue. As well as those quality checks a readability assessment of the legislation was obtained which was in turn peer reviewed. The assessment was based on linguistic testing for readability by all users of legislation, so not confined to lawyers, accountants and judges.

The Income Tax Bill was the largest Bill ever put before Parliament when it was introduced on 15 November 2006. ${ }^{54}$ It completed all the legislative processes and received the Royal Assent on 1 November 2007. As enacted it ran to 2,855 pages, including the contents table at 93 pages and the 52 schedules at 384 pages. The drafting intent was to make the alphanumeric numbered legislation as user friendly as was feasible and it regularly uses diagrams, flow charts, formulas, readers' notes and lists of defined sections as interpretation aids.

The continuing RAP has the responsibility for considering potential unintended changes emerging under the 2007 Act and the continuing consistency of amendments with the rewrite processes and objectives. It also considers any wider remedial matters on which the Minister of Revenue calls for submissions.

\section{FINAL COMMENTS}

What factors enabled the New Zealand rewrite to be completed with many favourable comments and with, it seems, no significant publicly expressed dissatisfaction?

Dr Adrian Sawyer, Professor of Taxation at the University of Canterbury and editor of the New Zealand Journal of Tax Law and Policy, discussed the history and significant features of the rewrite with extensive citing of published commendations. ${ }^{55}$ The abstract to the paper comments that: ${ }^{56}$

... without the influence of the RAP, the quality and accuracy of the Rewrite Program (including the

Income Tax Act 2007 NZ) would be much the poorer, with flow-on effects increasing compliance costs,

creating uncertainty and invoking more judicial involvement.

While happy to acknowledge that accolade for the Panel, I would answer the question posed above by suggesting that at least five factors were of particular significance.

54 Income Tax Act 1997, at 2855.

55 Adrian Sawyer "RAP(ping) in taxation: A review of New Zealand's Rewrite Advisory Panel and its potential for adaptation to other jurisdictions" (2008) 37 AT Rev 148.

56 At 148 . 


\section{A Collaborative Nature of Rewrite}

By 1994, the rewriting of the income tax legislation had become a collaborative exercise between the Government and key users of the legislation.

Various reviews and working parties in the 1980s built up widespread recognition within government and the private sector of the need to improve the quality of the legislation. By the time the first phase of the substantive rewrite followed on from the Income Tax Act 1994 incorporating the reordering and renumbering of the Income Tax Act 1976 and its amendments, the rewrite project had wide support in the House, in the Revenue and Treasury and amongst tax accountants and lawyers.

A striking example of what could be achieved by better drafting was highlighted in the Organisational Review Committee's tax report ${ }^{57}$ drawing from the Working Party's 1993 report. ${ }^{58}$ The Working Party Bill redrafted the core provisions of the Income Tax Act in 14 simply expressed sections and five pages of legislative text.

The Organisational Review Committee further demonstrated the need for simplicity in legislative drafting: ${ }^{59}$

An empirical study of the readability of New Zealand tax laws carried out by Tan and Tower was published in (1992) 9 ATF 355. The study focussed on amendments which had been passed after the Waugh Committee had strongly recommended that tax legislation be drafted in simple and clear language understandable to the ordinary taxpayer so that the intent of the legislation is clear. The study revealed that the average sentence length of the survey sample of income tax amendments post-Waugh was 135 words. After examining other indicators of readability including word length (syllables) and the use of the passive voice and comparing the results with pre-Waugh legislation, the study concluded that no progress had been made in simplifying the tax law to make it more readable and understandable. It concluded that tax legislation appeared to be very difficult to read by a high percentage of taxpayers. ... In a 1994 study by Tan and Tooley, 69 per cent of the tax practitioners surveyed considered tax legislation difficult to read. In commenting to the [Organisational] Review Committee on those findings, IRD agreed that tax legislation was very difficult to read and understand.

Those early initiatives garnered backing for the rewrite project with two important enduring consequences. First, successive National and Labour-led Governments backed the project. The personal support of successive Ministers of Finance and Ministers of Revenue was crucial in gaining the necessary funding and facilitating consideration of the mammoth Bills through the

57 Organisational Review Committee, above n 14, at 79.

58 Working Party on the Reorganisation of the Income Tax Act, above n 21.

59 Organisational Review Committee, above n 14, at 78. 
Parliamentary processes with cross-party support engendered in the Finance and Expenditure Committee and the House.

Second, a strong working partnership developed between public sector officials, (crucially the Inland Revenue Department led by Robin Oliver, Director of the Policy Advice Division and Deputy Commissioner), and the private sector (particularly through the Institute of Chartered Accountants and the New Zealand Law Society). That carried through to the deliberately small and stable membership of the RAP.

\section{B The First Phase Rewrite, 2004}

It is difficult to overstate the importance of the completion and enactment of the first phase of the substantive rewrite in 2004.

It was the first public test of the rewrite and was well received by users. It provided the platform on which the 2007 rewrite could build.

At the same time, it challenged the RAP to respond to difficulties which consideration of the 2004 draft had revealed in identifying and responding to potential unintended law changes arising in the rewriting of the legislation.

The processing of potential unintended changes, as they were raised by users in the course of what became the 2007 rewrite, has been discussed above at Part IV and does not call for repetition.

\section{Quality Control}

The extensive general quality checks built into the rewrite processes and summarised above at Part IV were designed to provide quality assurance.

The assurance of the qualities sought in the redraft was important as the work proceeded, in the passage of the Bill through the legislative processes and in the ultimate usability of the Act.

As well, the readability assessments were obtained because the RAP felt that, so far as can reasonably be achieved, small businesses and other ordinary taxpayers should be able to read and understand the legislation by which they are taxed, as should departmental officers and those preparing accounts for tax purposes, without being dependent on tax specialists.

\section{Goal Setting}

Setting and monitoring goals for the earliest achievable completion of the rewrite was important, particularly given that the first substantive phase of the rewrite had started in 1994 and the bulk of the rewriting still had to be done when the first Bill was before the House in 2003.

The RAP was conscious of the risks affecting the ultimate completion of lengthy reviews felt in other jurisdictions from rewrite and consultation fatigue, concerns over the continuing costs involved and changes in ministerial priorities. Focusing at every meeting on timelines and 
responding to any problems which emerged, all publicised on the website, also lifted the momentum and facilitated the early completion of what became the 2007 Act.

\section{E Small Group Commitment}

Finally, the rewrite processes gained immensely from the dedication of a small group of able and committed experts and officials working to a demanding timetable, particularly in later years, engaging outside expertise as and when required, as well as from the contribution of RAP members and the ministers involved. 